\title{
GROWING LUCERNE FOR DEHYDRATION
}

\author{
J. S. Whitelaw \\ Fletcher Agriculture, Ashburton
}

\section{INTRODUCTION}

LUCERNE has long been recognized as a highly nutritious forage crop, traditionally utilized for hay and now widely used for grazing stock on the shallower soils subject to summer drought. A recent commercial development in New Zealand is the use of lucerne to produce a dehydrated product. Export production from the Winslow factory has increased from 3000 tonnes in the first season to 14000 tonnes in the 1973-4 year, and, with an increasing lucerne contract area and plant expansion, production is planned to increase to 30000 tonnes.

Lucerne dry matter yield can be severely affected by drought conditions. It is essential, therefore, that lucerne crops are grown under irrigation, so as to fulfil export contract obligations and provide an even flow of green crop for efficient utilization of harvesting and dehydration plant. The decision to site dehydrators at Winslow, six miles south of Ashburton, was determined by many factors, such as the large area of flat land well served by good roads, the area already growing lucerne, railway facilities in proximity to ports, but the potential for lucerne production, with irrigation was a major consideration.

\section{CLIMATE}

Rainfall along the coastal strip is approximately $500 \mathrm{~mm}$ and this increases to $900 \mathrm{~mm}$ on the inland plains and downs, Ashburton average being $737 \mathrm{~mm}$. Temperature variation between years and months in the year can be very great. The maximum temperature (on the average) exceeds $27^{\circ} \mathrm{C}$ on 28 days in the year, and with wind on most days evaporation is high and effective rainfall is much less than recorded. At Winchmore Irrigation Research Station $(750 \mathrm{~mm}$ rainfall) the soil is at or below wilting point for 59 days on average each year and irrigation is essential for maximum lucerne production.

*This paper was prepared by the late J. S. Whitelaw and presented by A. J. D. Robb, Fletcher Agriculture, Dunedin. 


\section{SOILS}

Lucerne can be grown on a wide range of soil types, but in general terms the better the soil the better the yield. Soils on the Ministry of Works irrigation scheme areas are phases of Lismore silt loam. A thin veneer of loess blankets much of the fan surfaces but most of the scils are shallow with. stones in the topsoil. Lismore soils are suited for irrigation as their gentle relief and free drainage favour border-dyke irrigation systems. Soils under spray irrigation are brcadly Temuka silts and the shallow and sandy phases of the Wakanui series. Free drainage is important and lucerne sown on soils such as Temuka is at some risk in wet seasons or in times of excessively high ground-water levels. These deep moisture retentive soils can, however, produce high yielding crops without irrigation.

The history of lucerne production on flood-irrigated Lismore soils has not been good, as the lucerne soon lost vigour after two or three years of good yields of hay. Response to irrigation declined rapidly despite topdressing with lime and superphosphate, and the lucerne became rapidly invaded by grasses and weeds (Lauder, 1959). The reasons for this were most likely nutrient removale.g., potash-and lack of understanding of good management, coupled with establishment difficulties on new borders out of browr:top pastures. Lucerne stands lacked persistence under flood irrigation and, because of this, growing lucerne under this system came to be viewed with disfavour by most farmers. It is now known that disease can cause deterioration in the present New Zealand lucerne varieties grown under intensive irrigation, and this may also have been a factor. In spite of this problem history, flood-irrigated Lismore soils now make up nearly half the total irrigated contract crop area, because of improved growing techniques .

\section{CULTIVATION}

\section{NEED FOR LIME}

Growers are advised to begin with a soil test. This will not only determine the degree of soil acidity, but also indicate the amount of lime required to raise acid soils to, the desirable $\mathrm{pH}$ of 6.5.

As lucerne rhizobia will not 'survive in acid soils, adequate liming is essential and, if $\mathrm{pH}$ is less than 5.5, lime should be applied at least six months before sowing. Where this is not possible, the use of lime-coated seed is recommended. Where land 
is being prepared for flood irrigation, it is important that lime be applied after the grader work is completed to avoid mechanical movement of the lime.

\section{SEedbed Preparation}

Lucerne should not be sown in an area badly infested with twitch grasses, yarrow or grass grub, as even established lucerne is only moderately resistant to and not immune from grass grub attack. New lucerne has been very successfully established out of old grass on border dykes. Application of 'dalapon at 5.5 $\mathrm{kg} / \mathrm{ha}$, two weeks before surface cultivation, ensures a quick and positive kill of vegetation.

It is important that the seedbed be firm, and slow, even drilling, with $15 \mathrm{~cm}$ row spacing, on a heavily rolled seedbed, gives good results on stony soils. Cross-drilling often results in less satisfactory establishment than drilling in one direction only, and broadcast sowings are not recommended. A moist seedbed is necessary to germinate the seed. Seed should not be sown more deeply than $1.5 \mathrm{~cm}$ as lucerne needs to emerge rapidly.

\section{INOCULATION}

Lucerne, being a legume, must develop root nodules, containing an effective lucerne-specific strain of nitrogen-fixing bacteria or rhizobia, in order -that vigorous high-producing stands will develop. Because these lucerne rhizobia generally do not occur in the soil, they must be applied to the seed just prior to sowing. Two brands of peat-based inoculants are available in New Zealand. It is important that the directions for inoculating seed are followed carefully, and it is recommended that twice the usual amount of peat culture be added to seed as an extra precaution to ensure successful nodulation. As an alternative, coated seed can be used.

If the lucerne fails to nodulate (as shown by the yellow-green colour of the whole stand), it is possible to introduce rhizobia into the stand, by topdressing or drilling of special. granules. In this way ploughing of the stand is avoided.

\section{TIME OF SOWING}

Experience indicates that spring sowing is by far the most successful and autumn sowings are not recommended. On shallower soils lucerne can be sown as early as September, with 
early sowing giving better plant development before the onset of dry summer conditions. If the seedling stand can be irrigated in times of moisture stress, so much the better for root development and future production. The old adage that lucerne must not be irrigated in the seedling season is not correct.

\section{SeEding RAte}

Contract growers are advised to sow high-germination, machinedressed seed at not less than $11 \mathrm{~kg} / \mathrm{ha}$, and, in general, the higher the seed quality and the better the seedbed and soil types, the lower the seeding rate that can be satisfactory. Virtually all contract lucerne crops are sown with a cash cover crop, which provides increased competition for the establishing of seedlings.

\section{COVER CROPS}

Lucerne can be successfully established with cover cash crops, such as linseed, barley, wheat, or peas. Full sowing rates of linseed and wheat and short-strawed pea varieties are satisfactory, but if barley is sown on moisture-retentive soils or irrigated on any soil type, seeding should not exceed $85 \mathrm{~kg} / \mathrm{ha}$. Zephyr barley is preferred because of its short straw and less dense growth habit. It is most important that header tailings from cover crops be removed immediately after harvest, as trash overlying seedling lucerne that is already weakened from lack of light can result in high plant mortality.

\section{WEED CONTROI}

With efficient cutting management of dehydrated lucerne, grown with adequate fertilizer and irrigation, weed control is not normally required. However, when lucerne is sown alone, severe infestation of nodding thistle can occur at establishment. In this case the seedling crop should be sprayed with MCPB at $4 \mathrm{I} / \mathrm{ha}$ between the first and fifth true leaf stage, about $7.5 \mathrm{~cm}$ in height. The crop should not be sprayed if it has been recently heavy rolled.

\section{FERTILIZER}

Lucerne should be seeded with 250 to $500 \mathrm{~kg} / \mathrm{ha}$ of lucerne sowing fertilizer 0.7.0.8 or reverted molybdate superphosphate. "l'he higher rate should be used on less fertile stony soils. Super- 
phosphate must not be used because of its harmful effect on the rhizobia.

For maintenance fertilizer, the current recommendation for irrigated dehydrated lucerne is $1000 \mathrm{~kg} / \mathrm{ha}$ of lucerne high $\mathrm{K}$ fertilizer, with the addition of $15 \mathrm{~kg} / \mathrm{t}$ of fertilizer borate. Rates applied would vary from 630 to $1260 \mathrm{~kg} / \mathrm{ha}$. The basis for this recommendation is field observation and current trials. Under lucerne management for dehdyration, the total crop is harvested for processing and Dale (1967) has pointed out that the removal of nutrients is considerable. Maintenance fertilizer should be applied as one dressing in June/July or immediately after the first cut for the season. Foliage should be dry when fertilizer is applied to avoid damage from leaf burn.

\section{IRRIGATION}

To obtain highest yields the "crop must be grown free from moisture stress and irrigation water should be applied regardless of the stage of growth of the crop. Irrigation requirement can vary considerably from season to season, but on flood-irrigated Lismore soil between 5 and 10 irrigations could be necessary, but with spray irrigation on deeper soil only 3 to 5 irrigations are required each season. With flood irrigation, the efficiency of water use is markedly increased by as much as 50 to $70 \%$ with borders $200 \mathrm{~m}$ long, compared with $300 \mathrm{~m}$ or more, and this is an important point when planning new areas.

\section{CROP YieldS}

The highest recorded paddock yields from accurately -measured areas are $13500 \mathrm{~kg} / \mathrm{ha}$ on flood-irrigated Lismore soil and 16460 $\mathrm{kg} / \mathrm{ha}$ on spray-irrigated Wakanui silt loam. These stands lasted only three years and averaged $11210 \mathrm{~kg} / \mathrm{ha}$ and $14685 \mathrm{~kg} / \mathrm{ha}$, respectively, over the three seasons. Factors which limit yields are soils of natural low fertility, inadequate fertilizer and irrigation, stock grazing and loss of plant population due to disease.

\section{BActeriAl Wilt}

Bacterial wilt of lucerne (Corynebacterium insidiosum) was first identified in New Zealand in 1970 (Close and Mulcock, 1972). The disease is systemic and infection may be carried by all parts of the plant, including seed. Damage may occur in the first two years of a stand in a heavily infected area and the 
disease has been most severe in irrigated crops on deep soils. Early symptoms consist of leaf mottling, slight cupping of the leaflets, yellow coloration, and reduction in plant height, As the disease progresses, the symptoms: become more marked,. with marginal scorching of the leaves, severe stunting and proliferation of the stems giving "witch's broom" effect. When cut the main taproot of infected plants shows a yellow/brown discoloration of the vascular cylinder which contrasts markedly with the white colour of healthy plants. Many infected plants die, and so this disease can cause a serious depletion. Wairau and Chanticleer are both highly susceptible and for this reason Fletcher Agriculture has imported 20 resistant cultivars from the United States. Variety trials over the last two seasons have indicated that Saranac is likely to. be a suitable replacement for Wairau in areas known to be infected by bacterial wilt. New contract sowings this season (approximately 600 ha) will be seeded with Saranac imported for our growers.

\section{DEHYDRATION}

\section{Cutting S chedules}

Lucerne contracted for dehdyration should be ideally near to the processing factory but in practice contract areas can be up to $30 \mathrm{~km}$ from the plant. This permits a cutting programme from.

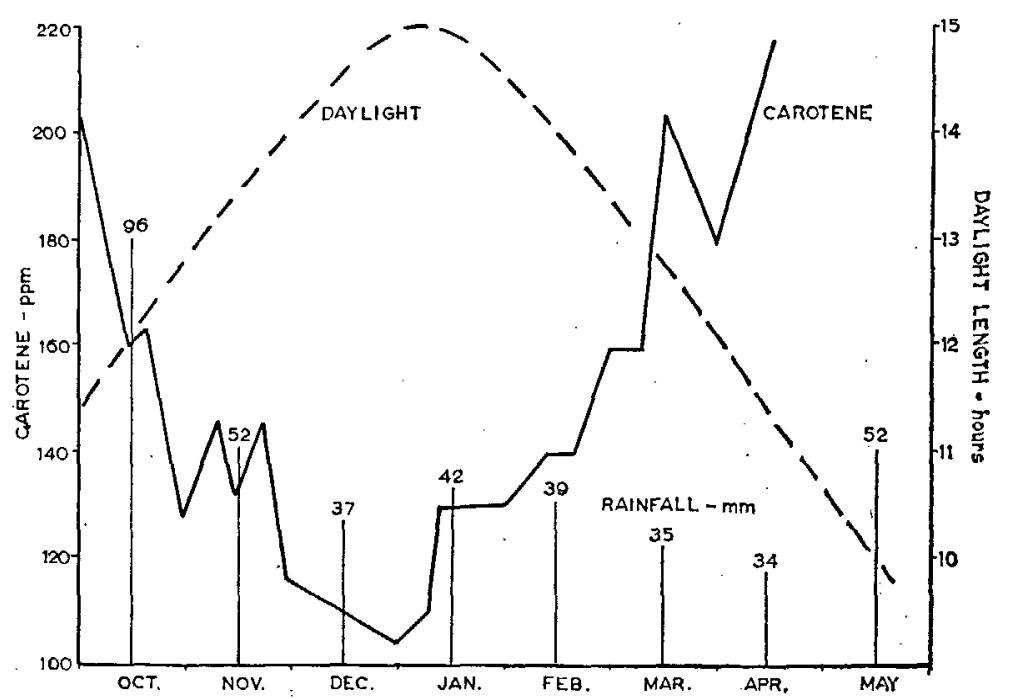

FIG. 1: Seasonal carotene content, dehydrated lucerne. 


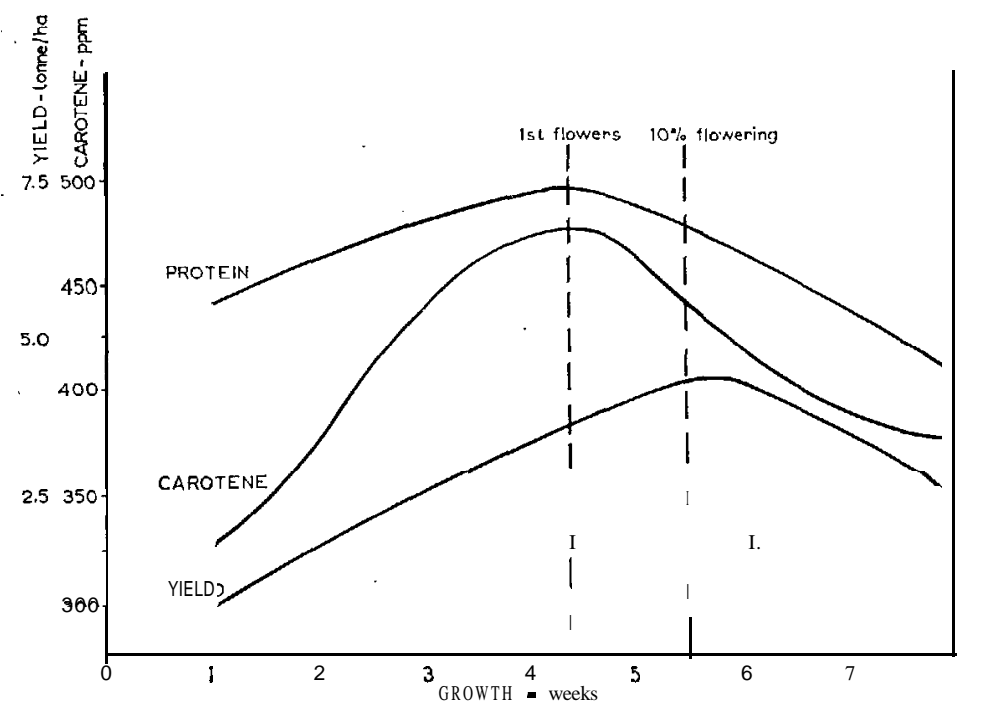

FIG 2: Lucerne growlh cycle.

early to late crops so that all lucerne can be harvested at close to the ideal stage for both maximum crop yield and highest quality. This is when the lucerne is at the $10 \%$ flower stage, with particular attention being paid to the emergence and height of basal shoots.

All crops are windrowed, the length of time in the windrow being decided by carotene content to give as much drying as possible in the field. Carotene analyses are carried out in the factory laboratory and harvesting schedules decided from the results. In general, longer windrowing periods are possible in the 'spring and autumn but during mid-summer these may be reduced to a matter of only hours. The windrowed crop is picked up and chopped to a uniform $2 \mathrm{~cm}$ length and transported to the processing plant in truck and trailer units. The green material is harvested over a 12-hour period and the raw material for night processing is stored on a concrete slab. Daily production normally requires 25 to 50 ha harvested to produce 170 tonnes of dry matter from 800 to 900 tonnes of green lucerne.

$$
\text { (. }
$$

\section{Method of Drying}

The finely chopped lucerne is fed to a revolving drum through which hot air from a'direct-fired oil burner is flowing. The water is flash-dried from the lucerne and the product carried in the air 
stream to cyclones where it is separated before hammer milling and pelleting. Plants are controlled by an operator who uses amp-meter and temperature readings to adjust operating variables by remote control.

\section{QUALITY CONTROL}

The export contract specifications are:

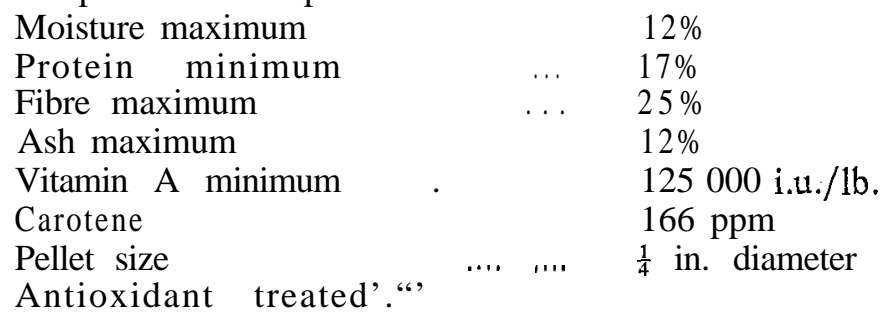

Strict process control is carried out both in the field and at the plant to ensure that specifications are continuously met.

\section{AVERAGE YIELDS}

The most important factor for reliable and acceptable yields of lucerne is moisture. Use of irrigatioa water provides reliable yields of 13 tonnes/ha on Mid-Canterbury medium to deep soils and 10 tonnes/ha on Lismore soils;

Typical grös margin analysis for irrigated lucerne at present prices and using Saranac bacterial-wilt-resistant lucerne having an estimated stand life of at least 4 years is as shown in Table 1.

The return from irrigated lucerne contracted for dehydration in Mid-Canterbury compares favourably with alternative cropping opportunities and this is evidenced by plantings of 450 ha in the 1974 spring.

\section{FUTURE PROSPECTS}

The reliable supply of dehydrated lucerne to Japan from a southern hemisphere source is desired by feed producers in that country. The carotene content diminishes on storage and as this is a desirable quality consideration fresh material has a strong advantage. Climatic factors in New Zealand differ from those in the previous northern season and provide a buffer against drought or other disaster.

With a high proportion of crop on irrigated land, MidCanterbury has over recent years become a reliable supplier, and with close technical control of harvesting and production quality 
TABLE 1: IRRIGATED LUCERNE-BASED ON 4-YEAR STAND LIFE WITH SARANAC

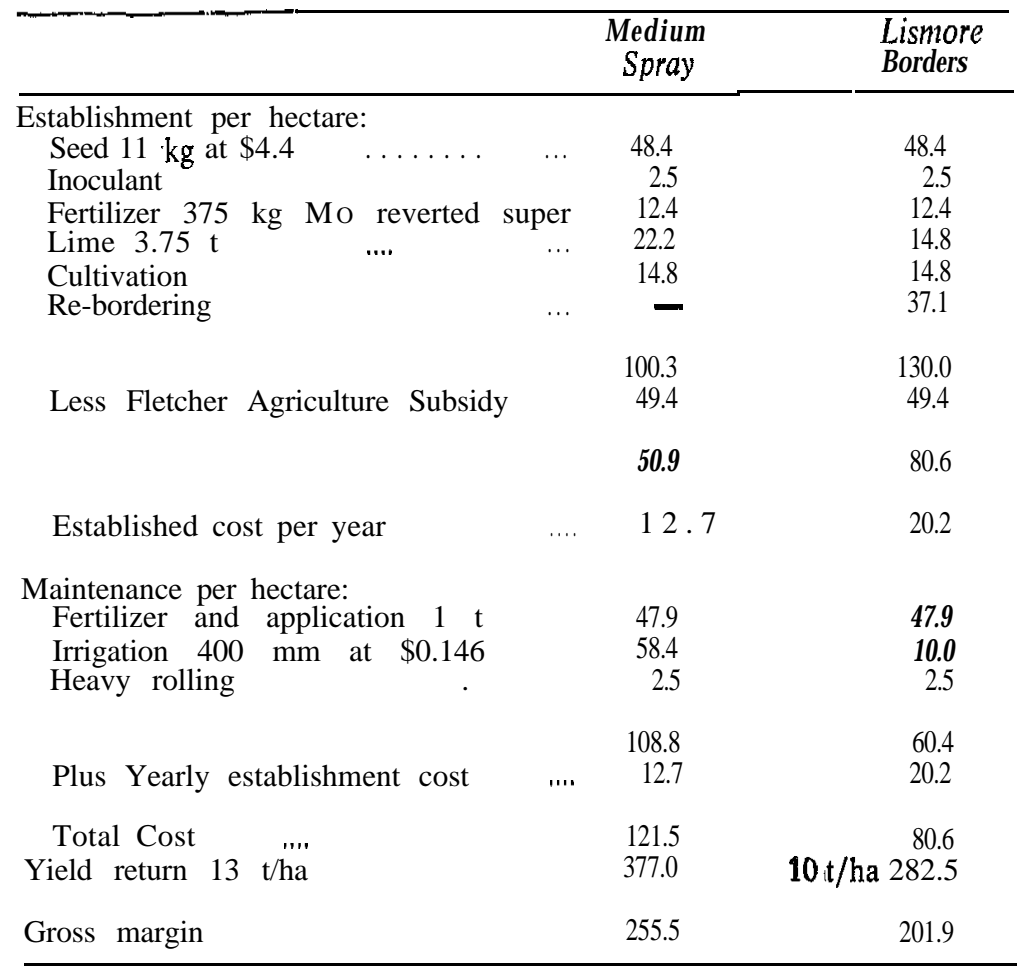

has been to specification. Variety, fertilizer, rate of sowing, and time of cutting trials are in progress and preliminary results from these have enabled growers to obtain reliable yields. Further applied research and development will provide growers with the equipment to obtain improved yields, reliability and quality in the future.

\section{REFERENCES}

Close, R.; Mulcock, A. P., 1972. Bacterial wilt Corynebacterium insidiosum (McCulloch, 1925) Jensen, 1934, of lucerne in New Zealand. N.Z. il agric. Res., 15: 141-8.

Dale, W. R., 1967. Fertilizer responses by lucerne in New Zealand. In The Lucerne Crop (Ed. R. H. M. Langer), Reed, Wellington. Pp. $134-42$.

Lauder, B. A., 1959. Lucerne irrigation trial at Winchmore. N.Z. /l Agric., 98: $57-60$ 